\title{
THE SOCIETY FOR THE STUDY OF FERTILITY, 1950-71
}

\author{
ALAN S. PARKES \\ Christ's College, Cambridge*
}

In June 1971, the Society completes 21 years of eventful life and this milestone in its history is an appropriate stage for a review of its aims and achievements.

Origin

The origin of the Society goes back to a small informal gathering in Exeter in 1944. Arthur Walton, a prominent participant, subsequently wrote of this meeting:

'In the Summer of 1944, under the auspices of the Family Planning Association and at the invitation of Dr Margaret Jackson and Mrs Clare Harvey, a small group of scientists interested in seminology met in the bombed city of Exeter. Our interests were widely representative of fundamental science, zoology, physiology, histology, human clinical medicine, agricultural science, veterinary practice and sociology, but we all had a common interest in problems connected with reproductive physiology and the diagnosis, prevention and cure of impaired fertility.'

I was not present, but it was evidently thought to have been a very useful event because plans were made for future informal meetings of the same kind. The second meeting in July 1945 was held in Cambridge in the Animal Research Station at the invitation of John Hammond and was attended by Margaret Jackson, Leslie and Clare Harvey, Arthur Walton, John Hammond and one or two others, including myself. Again the sessions were held at a week-end, so as not to interfere with the ordinary work of the participants, and I recall that much of the Sunday morning was taken up with a spirited sermon by Clare Harvey on abnormal forms of human spermatozoa.

The 1946 meeting was held in September at the National Institute for Medical Research in its old building in Hampstead, over a Saturday afternoon and Sunday, and attracted fifteen to twenty participants. As with the previous meetings, the emphasis was on seminology and infertility in man and animals. The highlight of this meeting, as I remember it, came from the statisticallyminded Cliff Emmens, who, following a paper on habitual abortion, stumped the speaker by saying that if, overall, one pregnancy in five ended in abortion then the odds against one woman having four in a row were not enormous, and asking whether, in fact, there was any such thing as an habitual aborter as distinct from a victim of probability. Unfortunately, no records of the programmes or participants at these first three meetings have survived.

* Address for reprint requests and correspondence: 7 Downing Place, Cambridge CB2 3EL. 
The 1947 meeting was held in the Nuffield Institute for Medical Research, then in the old Observatory, in Oxford. This meeting extended over 2 full days at the week-end following the XVIIth International Physiological Congress, a number of members of which, notably Professor H. H. Cole, attended the week-end meeting. The published proceedings of this meeting (see p. 319) had an introduction by Arthur Walton, from which the quotation at the beginning of this article is taken. A copy of the programme and a list of active participants are appended. In September of the following year, the meeting returned to the University College of the South West, Exeter. The emphasis continued to be on infertility, and in his foreword to the published proceedings Linton Snaith wrote: 'The choice of the Gity of Exeter as the centre for the fifth Congress on infertility implies no insult to the virility of the men of Devon'. By this time, participants numbered between thirty and forty, and the meetings were beginning to assume the nature of Annual Conferences on Infertility, a description used by Arthur Walton in his introduction to the published proceedings (see p. 319) of the 1949 meeting in Edinburgh. In these circumstances, it was evident that the complete informality of the organization could not be maintained indefinitely, and, at the close of the Edinburgh meeting, a small committee, with Gerald Swyer and Arthur Walton as joint secretaries, was set up to consider the possibility of forming a Society to carry on the work of the Conference. Discussions of one sort and another were carried on for many months, and it was finally agreed that, in the words of the notice of the 1950 meeting, signed by Gerald Swyer,

'A Conference on Fertility, which will also be the inaugural meeting of a new Society for the Study of Comparative Fertility, will be held in the House of the Zoological Society of London, Regents Park, London, N.W.1, on Friday and Saturday, 16th and 17th June.' [1950]

This announcement was noteworthy not only in foreshadowing the formation of the Society, but in switching the emphasis from the negative condition of infertility to the positive one of fertility, and although the word 'comparative' was dropped at the inaugural meeting so also was a proposal to alter the name to 'Society for the Study of Sterility'. The Constitution and Rules for the Society, adopted at this inaugural meeting, have been modified from time to time to meet changing circumstances, but were essentially similar to those in force today.

Although participants at the earlier meetings had usually taken the opportunity of dining together, the meeting at the Zoo was the first at which a Conference Dinner was held, and the tradition, now unhappily abandoned, that there should be no speeches at the Society's Annual Dinner dated from this first occasion, when some unknown bore jumped up and talked at enormous length about nothing.

\section{Development}

The programme of the inaugural meeting is reproduced in Appendix 3, which shows clearly the weight of medical and veterinary representation in the new Society (note the emphasis on qualifications). This emphasis was again seen in the programme of the 1951 meeting held in Girton College, Cambridge, 
and it persisted for many years, partly because of the origin of the Society in the study of infertility, and partly because biologists working in the physiology of reproduction showed little interest, at this stage, in the Society. Nevertheless, active steps were taken to ensure that the Officers, Chairman, Secretary and Treasurer, were representative of the different interests involved. Membership of the Society, happily, still includes a large number of practising medical men and women, but over the years, with the growth of the Society, the biological element has become uppermost in the Society, as may be seen from the programmes of the recent Annual Conferences, at which only the last session is now devoted to clinical matters. Correspondingly, a paper dealing with human material is a comparative rarity in the Fournal of Reproduction and Fertility. This trend may be said to have reached a climax in the Society's initiation and major participation in the International Symposia on Comparative Reproduction in Mammals, held at 4-yearly intervals, the first in London in 1964, the second in Nairobi (Kenya) in 1968 and the third, prospectively, in Edinburgh in 1972.

The growth of the Society in recent years has been remarkable. The inaugural meeting in 1950 was attended by about fifty members. In 1957, when I became Secretary (in opposition to the Committee's nomination!), members numbered about 120 . Four years later, membership passed the 200 mark and 3 years later again, in 1964, it was approaching 500 ; in 1967, it was over 700 and, at the end of 1970, the Society had 754 members. The critical increase in numbers thus took place in the first half of the 1960s. Of present numbers, of course, a large proportion are overseas and the attendance at the annual conferences is usually about 200 .

The growth of the Society has necessitated the multiplication of officers. From its inception, the Society, in addition to Chairman, Secretary, Treasurer and seven ordinary Committee members, serving 3-year terms of office, had an Editorial Secretary whose duty was to edit the Society's proceedings, which for 10 years were published in full (see p. 320). With the continued growth and increased activity of the Society, the office of Honorary Secretary became unsupportable. It had gradually become the custom to appoint a local conference secretary to supervise the local arrangements for the annual conferences and in 1966 this arrangement was written into the Rules. At the same time, the office of Secretary was further subdivided by making provision also for a Business Secretary and a Programme Secretary whose duties included editing the Society's ordinary proceedings. The office of Editor was retained to deal with the proceedings of the Society's symposia. The Conference and Business Secretaries have 1-year and 5-year terms of office respectively. The Editor's term is limited only by his stamina. A complete list to date is given in Appendix 4.

In 1964, the Society struck a medal to be known as the Marshall Medal of the Society in memory of Dr F. H. A. Marshall-the father-figure of reproductive physiology in Britain. Although Marshall was continuously in Cambridge from 1909 up to the time of his death 40 years later, it was most difficult to find a profile photograph from which an engraver could work for the obverse of the Medal, and in the end a half-full face photograph taken from a C.U.A.S. publication in 1926 was used, showing Marshall as a comparatively young man (Plate 1). The first recipient, most appropriately, was Dr Carl C. Hartman 
(see JRF, 9, 395), the second, Professor B. Zondek, who was presented with the medal at the Study group meeting arranged in his honour by the Ciba Foundation. The third recipient was Dr Herbert M. Evans (see JRF, 19, 2) and the fourth, Professor F. W. Rogers Brambell who received the Medal at the Society's annual dinner in 1969.

The finances of the Society were in a parlous state for many years, and I well remember, at one stage, an animated discussion as to whether the Treasurer could decently keep Heffers waiting still longer for settlement of the account for the last volume of Proceedings in order to be able to put down a deposit on the first volume of Studies on Fertility. The outcome of this historic debate is not recorded, but Studies on Fertility duly appeared.

At this time, 1955, the right of members to receive free copies of the published paper-back proceedings of the Annual Conferences had already proved a serious burden to the Society in spite of small but very welcome donations from a dozen or so pharmaceutical houses. It is not surprising, therefore, that the appearance of the first hardback in 1955 caused a financial crisis, which was met in 1956 by raising the subscription from one guinea to two guineas. When the Fournal of Reproduction and Fertility started in 1960 the subscription was further raised to three guineas, inclusive of the JRF which received 50s per member. In 1964, a two-tier subscription was introduced by which ordinary membership cost $£ 1$ and compound membership to include the Journal, $f^{5}$. Oddly enough, this arrangement was originally suggested, not because it was obviously sensible, but because of protests that where husband and wife were both members of the Society they did not want to be lumbered up with two copies of the Journal. The two-tier arrangement had the additional advantage that the Society now being approved by the Revenue, members could obtain tax relief not only on the ordinary subscription but also on the compound subscription, i.e. on the cost to them of the Journal.

In 1969, after the JRF had increased in size to nine issues in three volumes at a price of $£ 21$, and with the increasing cost of running the Society, ordinary membership was raised to $£^{2}$ and Compound A subscription to include the Journal, to $£ 8$. Compound $A$ was not changed when the Journal started monthly production and the price was increased to $£ 30$ in 1971 , so that members currently have the benefit of a $£ 24$ differential in obtaining the Journal. The Society has, therefore, had to tighten up conditions of membership, so that now a candidate needs a proposer, who must be of 3 years standing in the Society, and at least one supporter.

In 1964, when Bibliography of Reproduction became available to members at a slight reduction, two more compound subscriptions, Compound $B$ to include only BR and Compound $\mathrm{C}$ to include both JRF and BR, were introduced.

During his Chairmanship, Dr P. M. F. Bishop secured an annual grant of $£ 300$ for 3 years from ICI Pharmaceuticals; this, together with the rapidly increasing membership of the Society in the early 1960 s, put the finances on a comparatively sound footing and by 1968 attention was being turned to the desirability of giving some more formal structure to the Society, which at that time still had no legal existence. When the Society started in 1950, Sir John Hammond (then Dr Hammond) and Lord Rothschild were invited to become 
I'III: |

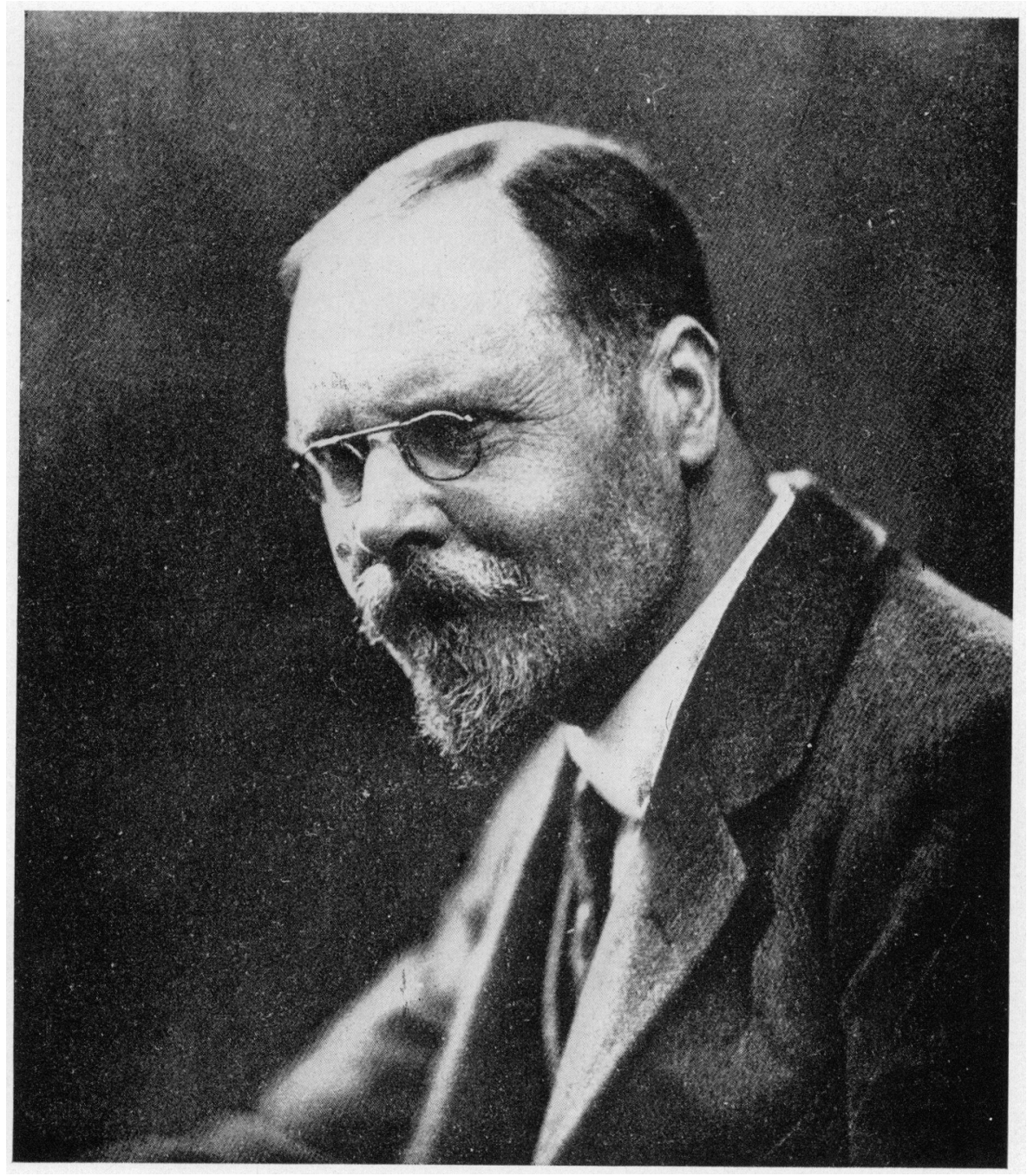

D) F.H. I. Marshall

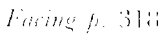


Trustees. Both accepted, Hammond with carefree enthusiasm, Rothschild after proper inquiry about financial responsibility. Neither was ever called upon and Hammond was not replaced after his death in 1964. In 1968, therefore, when the idea of giving the Society some legal entity was under discussion, advice was taken on the relative merits of a Company Limited by Guarantee and of a Trust. In the end, largely because of complications introduced by the Companies Acts of 1948 and 1967 it was decided to form a Trust and a Trust deed was drawn up with the following Trustees: L. A. Harvey, P. L. Krohn, Alan S. Parkes, Linton Snaith and Gerald I. M. Swyer. As a result the Society now has a legal existence, is comparatively comfortable financially and is well poised to develop further both its activity and its influence.

\section{Meetings}

The idea of meeting on Saturdays and Sundays did not survive the formation of the Society. As will be seen from Appendix 3, the inaugural meeting was held on Friday and Saturday, and in 1951 the principle of mid-week meetings was established, though in that year the meeting was still a 2-day affair, on Wednesday and Thursday. Over the years, the mid-week meetings gradually lengthened at both ends and now extend from Tuesday mid-day to Saturday mid-day. During this period in 1970, fifty-one papers were presented, twelve of them in the course of the two half-day symposia which have now become a feature of the annual conference. In its early days, the Society, by design, met alternately in and out of London. At the 1963 meeting in Nottingham, however, the advantages of being able to talk, eat, drink and sleep together under one roof became so obvious that a decision was taken in future to avoid London, where such accommodation was very difficult to find.

With the Annual Conferences firmly established, the Society began to organize short winter meetings. The first was scheduled for December 1967 but, owing to an epidemic of foot and mouth disease, was not held until February 1968. Further winter meetings took place in December 1968, 1969 and 1970, the first two of these being followed by joint meetings with the Blair Bell Research Society and the last one with the Association for the Study of Animal Behaviour.

\section{Publications of proceedings}

The Family Planning Association had shown an increasing interest in the small annual meetings which started in 1944, and financed the publication of the proceedings of the 1947 and 1948 meetings. The first ran to 64 and the second to 98 octavo pages, and both had the title, Conference on Infertility. Neither volume carries a publisher's imprint or a price, and it is not now clear whether they were sold or distributed free and, if so, to whom. History does not record the print number of these two booklets, but they are now very scarce and, for those who are interested, collectors' pieces.

At the 1949 Conference in Edinburgh, it was announced that the FPA had withdrawn its support and it was decided, among other things, to ask Heffers of Cambridge to undertake the publication of that meeting's proceedings in a format which would be suitable for the proceedings of the annual conferences of 
the projected Society. The resulting volume subsequently appeared with the somewhat premature title, Proceedings of the Society for the Study of Fertility No. 1, under the editorship of Arthur Walton who, in his Editorial note, bid farewell to the FPA and paid a graceful tribute to the Association's early assistance. Four further issues in this series were published to record the meetings of the Society in 1950, 1951, 1952 and 1953. These volumes increased in size from 44 pages of ordinary Journal size to 105 pages and were priced at $10 \mathrm{~s}$, but distributed to members of the new Society as part of the privileges of membership. The volumes were handsomely produced by Heffers, but being annual paperbacks, and for other reasons, the sales were negligible. As a result, the Society, which paid production costs, consistently lost money on them, and in spite of some support from outside sources, a change of policy became inevitable. Even as early as 1952 serious consideration was being given to the possibility of superseding the Heffer series of Proceedings by a quarterly Journal, and approaches were made among others, to Baillière Tyndall and Cox, Livingstone and H. K. Lewis. However, the idea foundered on the problems of how it was to be financed and who would take on the very considerable task of editing such a Journal. It was therefore decided to continue the annual volumes in a more saleable format. In the event, through the mediation of Professor R. G. Harrison, who also became Editor, arrangements were made for the publication by Blackwell Scientific Publications of the proceedings of the 1954 and subsequent annual conferences under the general title Studies on Fertility. These volumes were well turned out and sold reasonably well, but with a print number of 1000 all remained in print for some time after the last, recording the proceedings of the 1958 Conference, had been published. Several of these volumes contained papers additional to those given at relevant conferences, but they still suffered from being restricted to annual appearance.

With the appearance of the Fournal of Reproduction and Fertility, the proceedings were published only in abstract, other papers from the annual conference being submitted, if the author so wished, to the Journal in the ordinary way. This policy was not modified until after the 1967 meeting, when the proceedings of two symposia which formed part of that meeting, were published in full, in 1968, as Supplements 3 and 4 of the Journal. Similarly, Supplements 7, 8 and 9 recorded the proceedings of the symposia at the 1968 conference and Nos. 11 and 12 those of the 1969 meeting. Two more Supplements covering Symposia held in 1970 are to be published this year. From 1971 onwards supplements recording the Society's symposia will be issued to compounding members as part of the privileges of Compound membership.

\section{The Fournal of Reproduction and Fertility}

During 1957, the question of starting a quarterly Journal was again raised, and in July, as Secretary of the Society, I had a conversation with Mr Per Saugman of Blackwell Scientific Publications, who expressed satisfaction with the sales of Studies on Fertility and interest in publishing a quarterly Journal. He thought, however, that the support of a strong editorial board would be essential as well as some means of covering the inevitable losses over the first few years, which might add up to $£ 2000$. A suggestion for joint ownership by 
BSP and the Society was abandoned because those most closely concerned were strongly opposed to the idea of the Journal being owned, even partially, by a publisher. Later in the year, efforts were made to mobilize support for the project and I circulated to a number of non-members of the Society prominent in the field a memorandum asking their opinion of the proposal to establish a new Journal, especially as to whether adequate material and support would be forthcoming, and another one to editors of existing Journals asking whether they would view the prospect favourably and what effect they thought it might have on their flow of material. Generally, the response to these two memoranda was very favourable. The next problem was, of course, finance and after an abortive discussion of the possibility of forming a Partnership among a number of senior members of the Society to own and finance the Journal, it was decided that a number of Fellows of the Royal Society working in the field, whether or not members of the SSF, should make application to the Scientific Publications Board of the Royal Society. This was done during December and was rejected on the grounds that the function of the Board was to assist existing Journals in difficulty, not to facilitate the launching of new ones. Early in 1958, a similar application was made to the Nuffield Foundation, with a similar result. And there the matter rested for more than a year.

At the beginning of 1959 , as the result of a chance meeting in the Royal Society of Medicine with F. H. K. Green, then Secretary of the Wellcome Trust, I discovered, contrary to my previous understanding, that the Trust would not be prevented by its terms of reference from helping us and that an application might be considered favourably. Immediately following this piece of luck an application was made to the Trust and as a result I was able to announce at the AGM of the Society, in July 1959, that the Wellcome Trust had agreed to guarantee $£ 2000$ towards the probable losses incurred in establishing the proposed new Journal. This information was received enthusiastically and the work of organizing began.

Those mainly interested in the projected Journal had several considerations in mind: (a) the Society was not incorporated in any way and had no legal standing, (b) it was growing rapidly and already contained a large proportion of overseas members, (c) a great deal of work would have to be devoted to launching and establishing the Journal, and (d) the Journal, if successful, could easily become a major financial undertaking which would require constant supervision on the business side, a forecast which has proved to be almost frighteningly correct-overall sales in 1971 are likely to be of the order of $£, 50,000$.

It was decided, therefore, that the Journal should not be owned and managed by the Society, but should be launched by a small number of senior members of the Society, incorporated as a Company limited by guarantee and not having a share capital-a set-up which had proved very satisfactory in the early days of the Fournal of Endocrinology.

This Company was duly incorporated on 25th January 1960 as Journals of Reproduction and Fertility Ltd, a title meant to cover the possibility of launching a second Journal at some future date. The Memorandum and Articles of Association were signed in this order by A. S. Parkes, G. R. Austin, Margaret C. N. 
Jackson, P. M. F. Bishop, E. C. Amoroso, J. A. Laing, R. A. Beatty, G. I. M. Swyer, T. R. R. Mann, L. E. A. Rowson, R. G. Harrison, J. Edwards and Patricia P. Scott. The thirteen signatories became the first members of the Council of Management as well as the first members of the Company. These thirteen members remained in office until 1962, when, the Journal having become firmly established, retirement and replacement in rotation was organized by enlarging the Council to fifteen members to allow a 5-year term of office with three members retiring each year. At the ballot to decide the order of retirement of members of the existing Council, on which $I$ had been serving as Secretary, my name came first out of the hat, and to maintain continuity on the business side, I was appointed acting unpaid unqualified Company Secretary, an employee of the Council. At the same time re-enforcement of the members of the Company was begun by the election to it each year of members of the Society's Committee not already members of the Company.

G. R. Austin became the first editor, with an Editorial Board of twelve members. The Registered Office of the Company and the Editorial Office, therefore, were initially at the National Institute for Medical Research, but were moved to the Physiological Laboratory, Cambridge, on the removal of the Editor and Secretary to that Department. The first issue appeared in February 1960, and contained many of the papers given at the Society's 1959 Conference and abstracts or titles of the rest. In 1962, it became necessary to expand the Journal to six issues a year to give two volumes and Austin was joined by J. S. Perry as Associate Editor. A year later the Editorial Office was moved to the ARC Institute of Animal Physiology, where more accommodation was available. This arrangement continued until the middle of 1964, when the simultaneous disappearance of Austin to the United States and of Perry to Nature caused an editorial crisis. By this time, Miss Oona Ault had joined the team as Editorial Assistant and it was resolved to convert the Editorial Board into a Panel of Associate Editors with much wider powers and that I should act as Executive Editor. A small room was rented as Editorial Office at 8 Jesus Lane, Cambridge, in the accommodation occupied by Mr Donn Casey's Reproduction Research Information Service and here Miss Ault, with only casual secretarial help, performed the remarkable feat of integrating the work of two dozen or so Associate Editors dealing with around 200 papers a year, and seeing to and through the press an average of 1100 pages a year.

In 1967, it became necessary to plan for further expansion of the Journal to nine issues and additional accommodation was obtained at 8 Jesus Lane. Simultaneously, Mrs M. A. Herbertson joined the staff as a part-time Assistant and regular secretarial help was obtained. In 1968, 346 papers were submitted and nearly 1600 pages published, and the need for a full-time, salaried, scientifically and medically qualified Editor became imperative. In the autumn of that year, Dr D. J. Bartlett was appointed Editor, I became Consultant Editor and the Panel of Associate Editors reverted to an Editorial Board. Two years later, a new and more favourable contract was negotiated with Blackwell Scientific Publications and arrangements made to produce twelve issues at monthly intervals in 1971, the price being further raised to $£ 30$ p.a. In 1970 , also, the Journal Company was formally recognized by the Charity Commis- 
sioners and registered as a Charity, thus consolidating the position with the Inland Revenue, making possible the reclaim of SET, and entitling the Company to a $50 \%$ reduction on local rates. At the same time, the Company leased a small house at 7 Downing Place to accommodate both Company and Editorial offices, which, in addition to giving more accommodation, has the great advantage of being within a few yards of the Physiological Laboratory and the other biological departments on the Downing site.

The decision, in 1965, to publish supplements to the Journal arose from an inquiry by the Upjohn Company as to whether we could publish the proceedings of the Second Brook Lodge Workshop, which dealt with Ovarian Ovulatory Mechanisms. The Council of Management agreed in principle, and as the proceedings were much too long to be included in a regular issue of the Journal, and as Upjohn offered favourable terms, this seemed a good opportunity to start a supplement series. Supplement No. 1 thus appeared in 1966. Since then, two more Brook Lodge Workshops have been published as Supplements, and the proceedings of a Wyeth Symposium as Supplement No. 5. A shortened edition of the latter created something of a record for a supplement to a scientific Journal of this kind by having a print number of 50,000. Supplements containing the proceedings of symposia held at the Annual Conferences of the Society have already been mentioned. The remaining supplement, No. 6, contained the proceedings of the Nairobi Symposium on Reproduction in Mammals and ran to 520 pages. The Supplement series is proving to be a most successful venture.

During 1961, the Editor of the Journal received a suggestion from an Australian source, that a special issue should be inscribed in honour of Sir John Hammond. The suggestion was received with enthusiasm and the project grew to include an almost verbatim account of an interview with him, an assessment of his contribution to science and to animal production and reproduction, a curriculum vitae and a selected bibliography. The result can be seen in JRF 3,1 . The success of this venture prompted two more similar ones, in honour of Professor Bernhard Zondek and of Dr Herbert M. Evans, the results of which appeared in JRF, 12, 1 and 19, 1, respectively. These honorific issues are designed to put some flesh on the dry bones of history and they will certainly be continued.

\section{Epilogue}

So ends the first 21 years in the life of the Society for the Study of Fertility and the first 11 years of publication by its official Journal. From this piece of history one lesson can be learnt, if learning is necessary - that given enthusiasm and a slice of luck, thriving enterprises can spring from small and even casual beginnings. And the SSF is certainly thriving. The older members of the Society, on its 21 st birthday, can look back with pride on past achievements and the younger ones can look forward with quizzical anticipation to celebrating its Jubilee in A.D. 2000. 
APPENDIX 1. Exact copy of the programme of the 1947 meeting

The Family Planning Association

CONFERENGE ON INFERTILITY

held at

\section{The Nuffield Institute for Medical Research, Oxford July 26th and 27th, 1947}

SATURDAY, JULY 26th

11 a.m.

1. The Influence of $\mathrm{pH}$ and Tonicity on the Viability of Spermatozoa

2. Observations on the Activity of Spermatozoa in Relation to their Density

Part 1 (Experimental)

Part 2 (Application to Clinical Studies)

3. Some Observations on the Bacteriology of Bovine Semen

2.30 p.m.

4. Some Experiences of a Fertility Clinic

5. Spermateleosis and the Functions of the Epididymis

6. Secretory Functions of Seminal Vesicles
Ghairman: Dr. A. Walton

Dr. C. W. Emmens

Dr. G. I. M. Swyer

Dr. G. Kennedy

Mr. W. R. Kelly, M.R.G.V.s. 
APPENDIX 2. Exact copy of the list of active participants at the 1947 meeting

\section{THE FAMILY PLANNING ASSOGIATION CONFERENGE ON INFERTILITY}

The following members of the Conference contributed to the lively and illuminating discussions which followed each paper:-

\begin{tabular}{|c|c|c|c|c|c|c|}
\hline Dr. Irving Bell & & $\cdots$ & $\cdot$. & $\cdots$ & $\cdots$ & Bristol \\
\hline Professor Rogers Bram & abell & $\ldots$ & $\cdots$ & $\ldots$ & $\ldots$ & Bangor \\
\hline Mr. Clift & ... & $\ldots$ & $\ldots$ & $\ldots$ & $\ldots$ & Groydon \\
\hline Mr. Glark & $\ldots$ & $\ldots$ & $\ldots$ & $\ldots$ & $\ldots$ & IIminster \\
\hline Professor H. H. Cole & $\ldots$ & $\ldots$ & $\ldots$ & $\cdots$ & $\ldots$ & California \\
\hline Dr. Cross & $\ldots$ & $\ldots$ & $\cdots$ & $\ldots$ & $\ldots$ & Dublin \\
\hline Dr. Davidson & $\ldots$ & $\ldots$ & $\ldots$ & $\ldots$ & $\ldots$ & London \\
\hline Dr. Emmens & $\ldots$ & $\ldots$ & $\ldots$ & $\ldots$ & $\ldots$ & M.R.C. \\
\hline Miss Field Richards & $\ldots$ & $\ldots$ & $\ldots$ & $\ldots$ & $\ldots$ & London \\
\hline Dr. Friedman ... & $\cdots$ & $\cdots$ & $\ldots$ & $\ldots$ & $\ldots$ & London \\
\hline Dr. Griffith & $\ldots$ & $\ldots$ & $\ldots$ & $\ldots$ & $\cdots$ & London \\
\hline Dr. J. Hammond & $\ldots$ & $\ldots$ & $\ldots$ & $\ldots$ & $\ldots$ & Cambridge \\
\hline Dr. and Mrs. Harvey & $\ldots$ & $\ldots$ & $\ldots$ & $\ldots$ & $\ldots$ & Exeter \\
\hline Dr. Margaret Jackson & & $\cdots$ & $\ldots$ & $\ldots$ & $\ldots$ & Exeter \\
\hline Mr. Kennedy ... & $\ldots$ & $\ldots$ & $\ldots$ & $\ldots$ & $\ldots$ & London \\
\hline Miss Lorlaw & $\ldots$ & $\ldots$ & $\ldots$ & $\ldots$ & $\cdots$ & Oxford \\
\hline Dr. G. Macleod & $\ldots$ & $\ldots$ & $\cdots$ & $\cdots$ & $\cdots$ & New York \\
\hline Dr. T. Mann & ... & $\cdots$ & $\ldots$ & $\cdots$ & $\cdots$ & Cambridge \\
\hline Miss Moore White & ... & $\ldots$ & $\ldots$ & $\ldots$ & $\ldots$ & London \\
\hline Dr. W. H. Merivale & $\ldots$ & $\ldots$ & $\ldots$ & $\ldots$ & $\ldots$ & Newcastle \\
\hline Dr. Parkes & $\ldots$ & $\ldots$ & $\ldots$ & $\ldots$ & $\ldots$ & M.R.C. \\
\hline Dr. Sandler & $\ldots$ & $\ldots$ & $\ldots$ & $\ldots$ & $\ldots$ & Manchester \\
\hline Dr. Scott Blair & $\ldots$ & $\ldots$ & $\ldots$ & $\ldots$ & $\ldots$ & Reading \\
\hline Mr. Albert Sharman & ... & $\cdots$ & $\cdots$ & $\cdots$ & $\cdots$ & Glasgow \\
\hline Dr. Frances Shields & $\ldots$ & $\ldots$ & $\cdots$ & $\ldots$ & $\cdots$ & New York \\
\hline Mr. Linton Snaith & ... & $\cdots$ & $\cdots$ & $\ldots$ & $\ldots$ & Newcastle \\
\hline Mr. John Stallworthy & & $\ldots$ & $\ldots$ & $\ldots$ & $\ldots$ & Oxford \\
\hline Dr. Swyer & $\ldots$ & $\ldots$ & $\ldots$ & $\ldots$ & $\ldots$ & London \\
\hline Dr. Walton & $\ldots$ & $\ldots$ & $\ldots$ & $\ldots$ & $\ldots$ & Cambridge \\
\hline Mr. Wynn-Williams & $\ldots$ & $\ldots$ & $\ldots$ & $\ldots$ & $\ldots$ & London \\
\hline
\end{tabular}




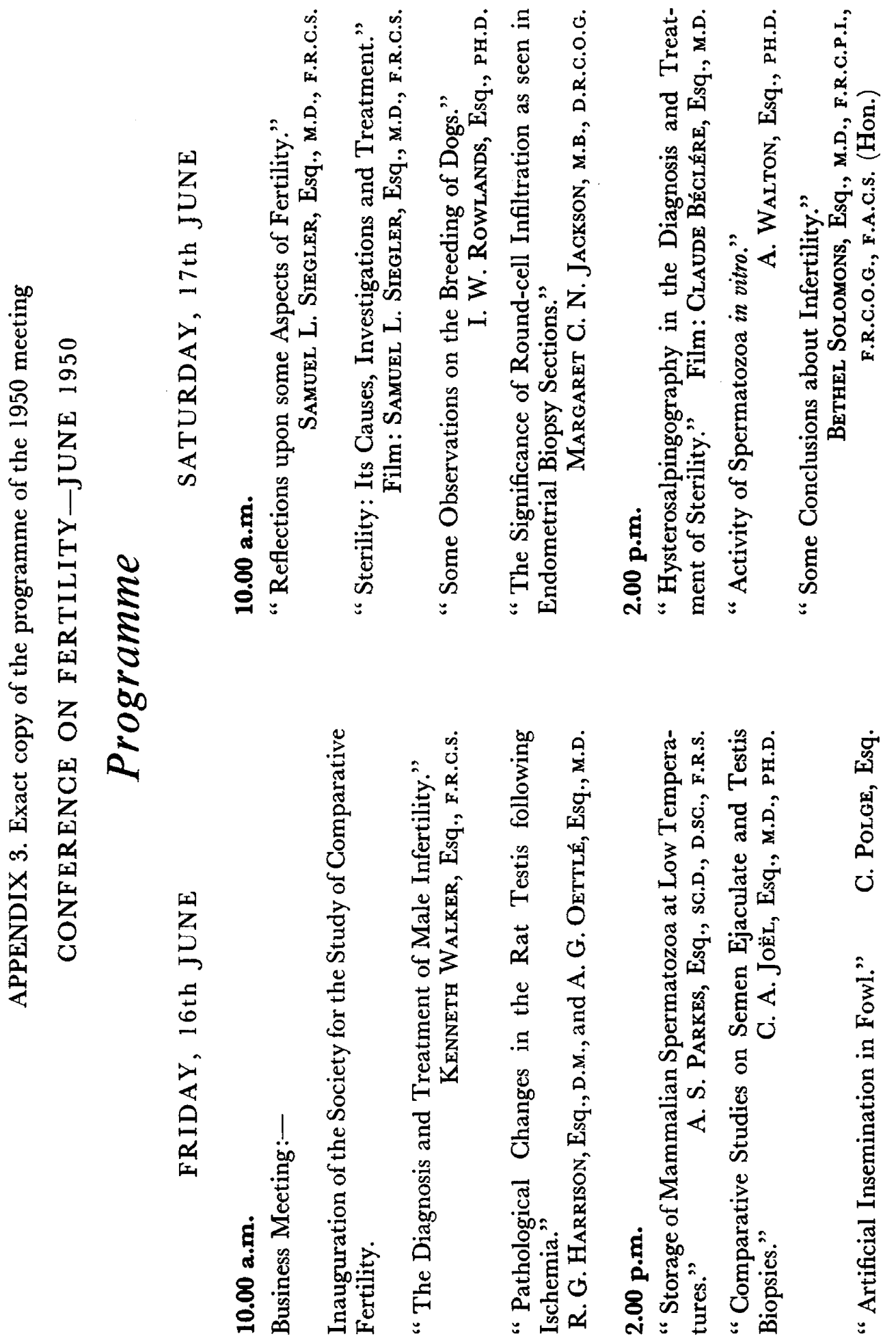




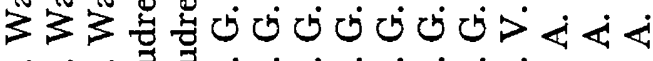
ه广
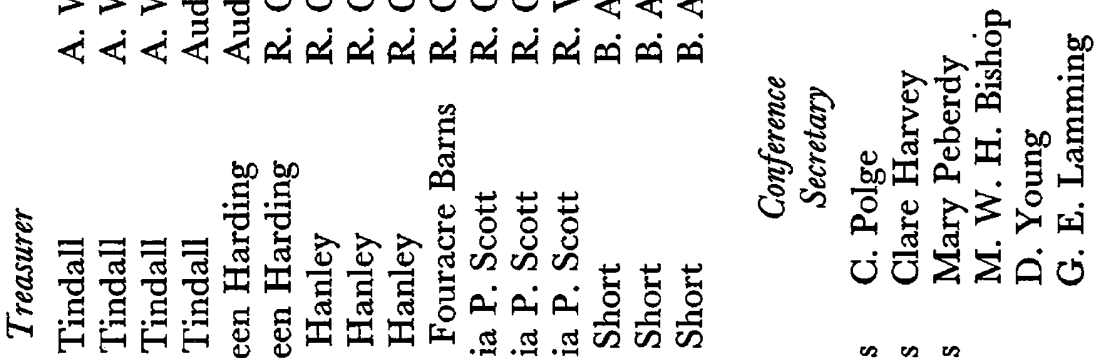

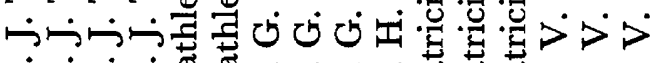

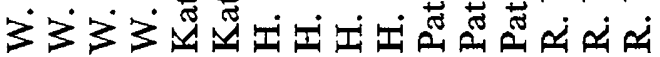

营

ธี ㅇํㅇ

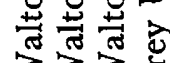

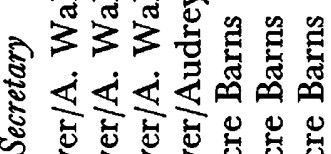

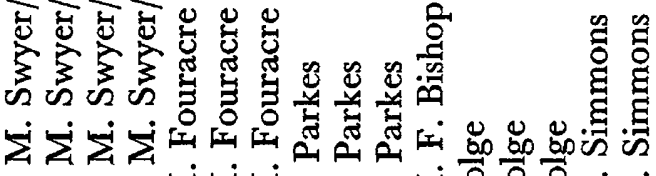
ن்

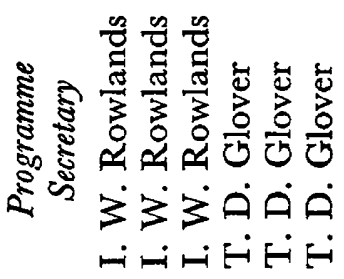

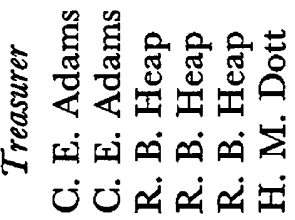

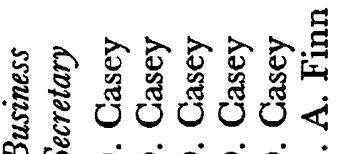

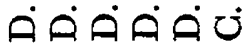
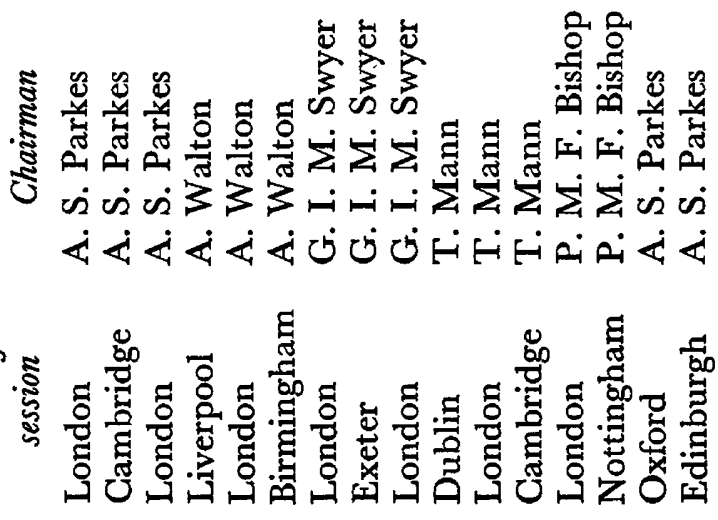

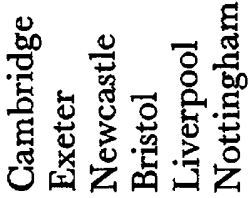

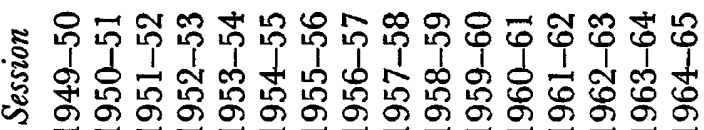

눙융요유준 101100

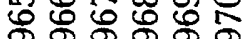

